\title{
The Comparison and Contrast of Higher Education Entrance Examination System in China and Nigeria; Lecturers' Perspective.
}

\author{
Moses Oladele Ogunniran ${ }^{1} \quad$ Longlong $\mathrm{Hou}^{2}$ * \\ 1.Institute of Comparative Education (Educational Leadership and Policy), Xinjiekouwai Street No.19, Faculty \\ of Education, Beijing Normal University, Haidian District, Beijing, China, 100875. \\ 2.Faculty of Education, Xinjiekouwai Street No.19, Faculty of Education, Beijing Normal University, Haidian \\ District, Beijing, China, 100875. \\ *Email of Corresponding Author: houll@bnu.edu.cn
}

This research is finance by: China National Education Science Planning on the general Project "Study on Synergy Effect of Incentive Policy For Primary and Secondary School Teachers".

\section{Abstract}

Literatures were reviewed based on the study with classical test theory (CTT). Purposive sampling technique was used to select University of Ibadan in Nigeria and Beijing Normal University in China while snowball sampling approach was used to select one hundred and twenty-two (122) lecturers in Beijing Normal University in China and 100 (one hundred) lecturers in University of Ibadan in Nigeria making a total of 222 (two hundred and twenty-two) respondents (lecturers) in both countries. Three objectives were generated for this study. Descriptive statistics of frequency counts was used in analysing the results. The findings revealed that lecturers' perspective of Gaokao was that there should be another screening exercise for students after passing Gaokao. The findings also showed lecturers' perspective of Waec/Utme was that the presence of Post-UTME screening exercise for students after passing UTME was the best. The paper recommended that Chinese government should embark on programmes that will reorientate Chinese students on all examinations especially university entrance examination Gaokao. Nigerian government should allow score obtained in the UTME to be used for admission for more than one year.

Keywords: Higher education entrance examination, lecturers' perspective, Chinese Gaokao, Nigeria Waec/Utme, China and Nigeria education system.

DOI: $10.7176 / \mathrm{JEP} / 10-11-03$

Publication date: April $30^{\text {th }} 2019$

\section{Acknowledgment:}

I would like to express my profound gratitude to the persons below who made this project a success and has assisted me at every point to cherish my goal:

My Supervisor, Prof. Hou Longlong for his vital support and assistance. His encouragement made it possible to achieve my aim in publishing this project.

Secondly, Prof. David Turner whose constant help and forthright attitude at every point has helped me to work in time.

I really appreciate their selfless effort and I wish to continually follow their academic hallmark to achieve my career goals.

Thank you Professors.

\subsection{INTRODUCTION}

\subsection{Background to the Study}

Lecturers' perspective on GAOKAO and WAEC/UTME are not only important because lecturers are stakeholders in both countries but also because they have a foundational knowledge and they had passed through GAOKAO and WAEC/UTME in their various countries. However, lecturers also partake in higher education system/process in terms of research, teaching/lecturing, evaluation, academic interaction with student etc.

Nigeria and China have education policy concerning higher entrance examination. In Nigeria it is known as WAEC/UTME while China referred to it as 'the Gaokao Examination Policy' which was adopted in 1952 by the newly founded People's Republic of China. (Bai, Chi, and Qian, 2014). Both higher entrance examinations take place annually. Candidates that write the examination in Nigeria is over one million while that of China over nine million (Schroch, 2014).

Higher education/Tertiary education entrance examination is generally considered as the major pillar that enhances individual educational goals and development worldwide. In the present model/framework of lifelonglearning, higher education is not only meant to provide progressive skills, critical thinking ability or knowledge that is fully required by labour market, but it also generally enhances practical training express needed by all profession either at technological level, humanist, medical science or the social sciences. 
These therefore, enhance the trained student to be critical involved in playing a higher role in effectively improving and developing a nation. The strategy involved in selection of the student into higher education is what is called admission or entrance examination, which depends on every country context. These admission process into higher education is often done by student towards the year of their secondary last level. However, most countries government institution are faced with the responsibility of conducting this entrance examination and then the examination result will determine the student placement into higher education. The process and strategy involves in the selection of students into higher education lead to an "unsurprisingly untidy world of tertiary admission practices, together with an array of concerns and challenges" Robin (2008, p.1).

As each country has their own selection approaches for admitting students into the universities, the Chinese higher education entrance examination system for example, is categorized as a centrally coordinated exam while that of Nigeria is categorized under the individual institution for the selection process. GAOKAO, the high school test examination, is an achievement based test and national higher education entrance examination in the People's Republic of China. It is also known as National Matriculation Examination (NME) or National College Entrance Examination (NCEE). In this examination, candidates are required to sit for three compulsory subjects which are Chinese, Mathematics and one foreign language. This foreign language could be English, Japanese, Russian or French. There are other six standard subjects which are three sciences (Physics, Chemistry and Biology) and three humanities (History, Geography and Political Education). Candidates' course will determine which of the category to choose from.

\subsection{Rationale for comparing China and Nigeria higher education entrance examination and its relevance}

Globalization is leading to a greater mobility of students not only going from one country to another but also from one continent to another, and each continent's higher education (HE) is benefiting from the recruitment in this mobility of students. There is therefore need for HE admission officers, tutors, staff and students to be fully aware of the qualifications that may be offered by applicants from other countries. Both China and Nigeria has a high population of higher education student as in Asian, China is the highest populous nation and in Africa, Nigeria is largest in population. In this regards, it is assume that both nation will share similar challenges involve in higher education entrance examination. However, as result of globalization, China/Africa cooperation, student mobility from Nigeria to China, this paper will help to serve as background information of both countries higher education system. Moreover, the political maps in Asian and Africa are constantly changing and this is affecting the educational systems and qualifications offered by potential applicants from one country to another (UCAS, 2015). It is based on this premise that table 1.1 below compares China and Nigeria entrance examination to the practice of accepting students for admission within and outside the two countries. The table provides evaluation of students and their qualifications, grading system and distribution of grades, educational system together with an insight into the requirements within each country.

Table 1.1: China and Nigeria Higher Education Entrance Examination System

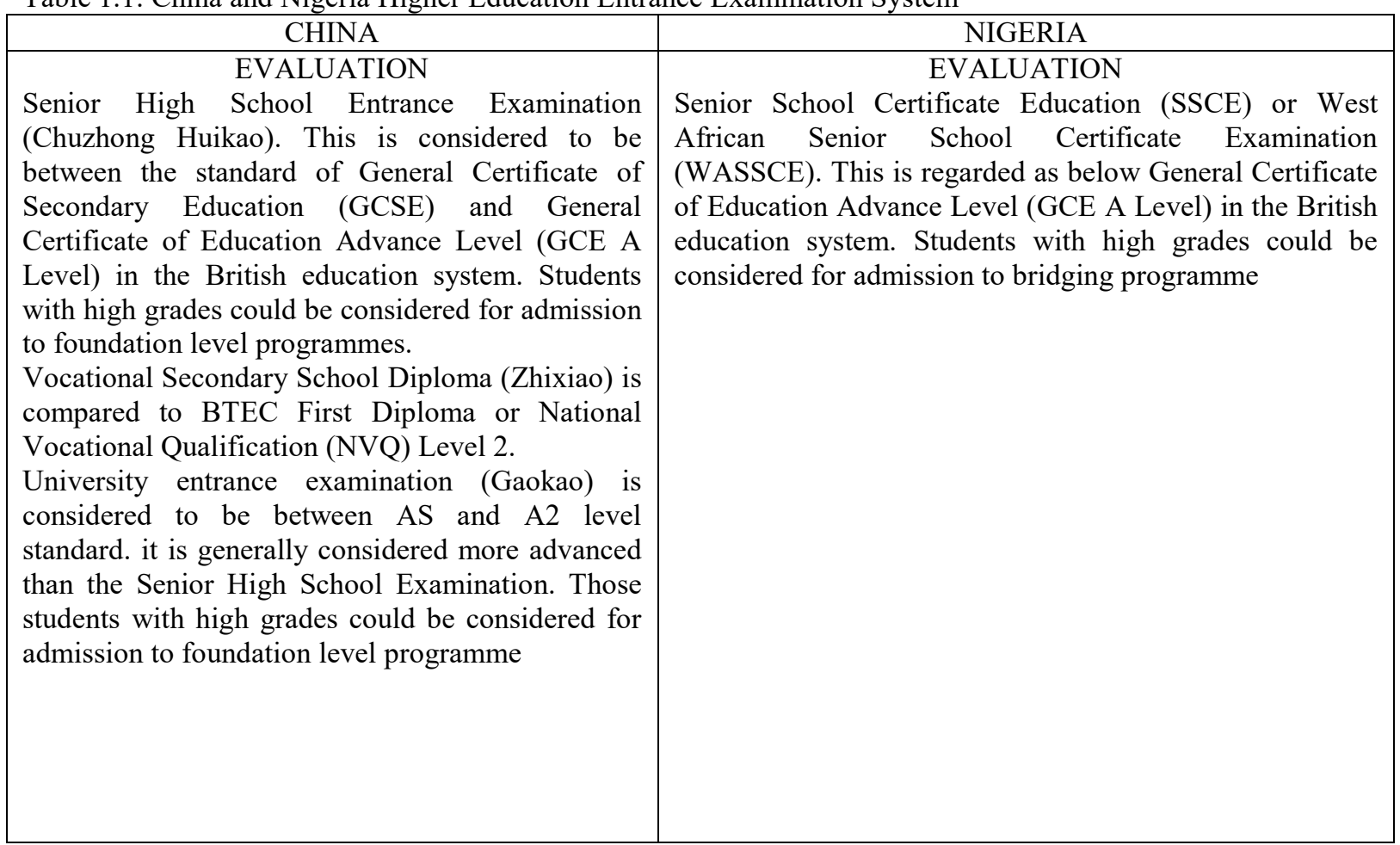




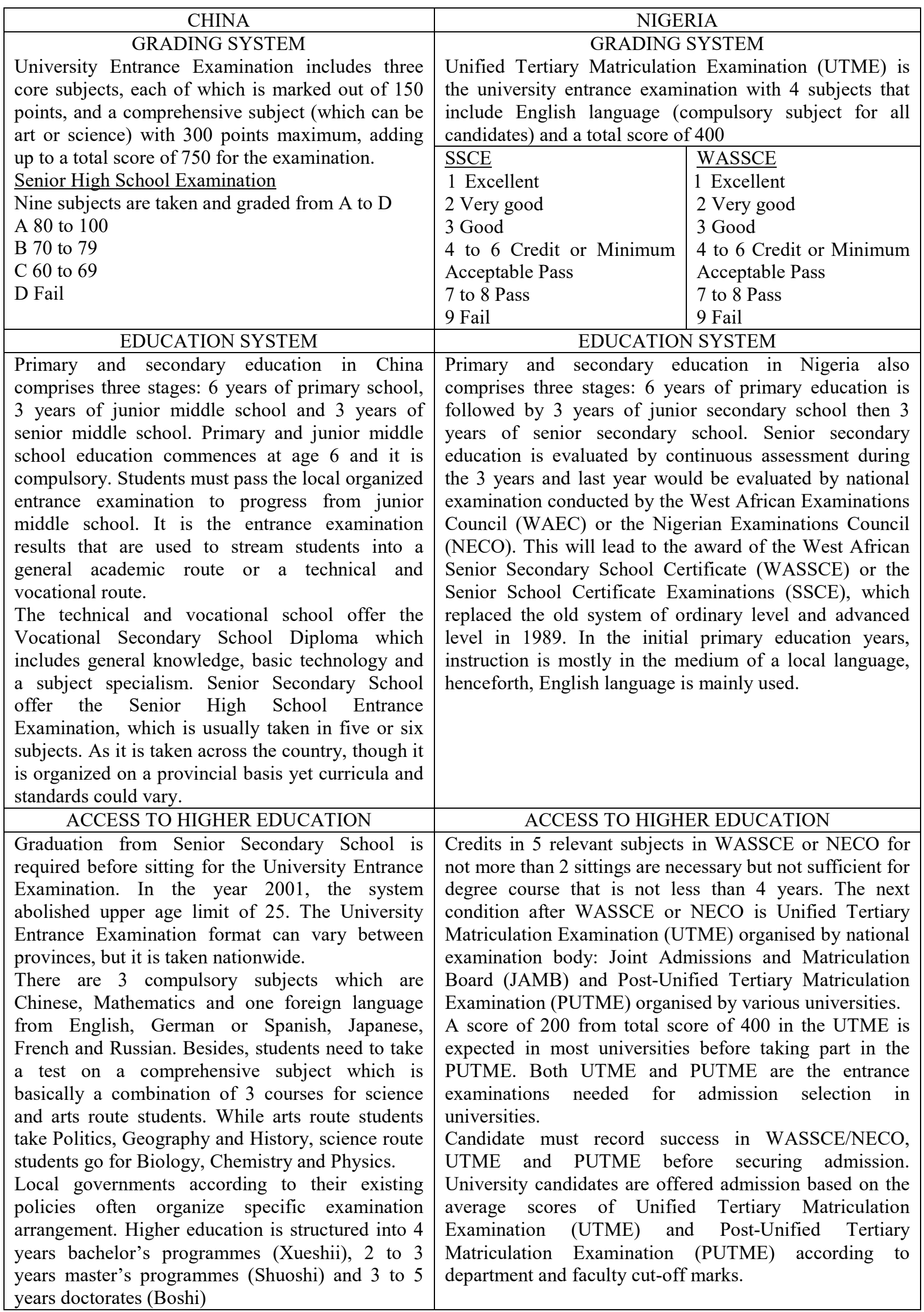

Over several decades, demand for university education across the world has enormously increased. The 
reason for this increase could be link to how university education provides quality education, preparing students in relevant knowledge and skills required by the labour market. The standard of this university education could be affected by the quality of students given admission into the university which in turn depends on mode of university entrance examination or admission. Despite huge success and sometimes very high score in higher entrance examination, there is still poor performance of students admitted into the different courses in the universities. This has become a source of worry to stakeholders of university education. The predictive power of entrance examination has been frequently reviewed since it remains the only selection process for admission into the universities. In spite of some progress in teaching, research and community services, it is observed that there is still dearth of studies on higher entrance examination. Hence, the researcher sees that it is necessary to investigate comparative study of lecturers' perspective of university entrance examination using the case of Gaokao and Waec/Utme in China and Nigeria education system.

\subsection{The main objective of this study}

The objective of the study is to examine and compare lecturers' perspective of university entrance examination using Gaokao and Waec/Utme in China and Nigeria education system as a case study. The study specifically sought to investigate the following objectives:

(i) Lecturers' perspective of Gaokao as university entrance examination in China education system.

(ii) Lecturers' perspective of Waec/Utme as university entrance examination in Nigeria education system.

(iii) Comparison between lecturers' perspective of Gaokao and Waec/Utme in China and Nigeria.

\subsection{Research Questions}

The following research questions were answered during the course of the study.

(i) What is the lecturers' perspective of Gaokao as university entrance examination in China education system?

(ii) What is the lecturers' perspective of Waec/Utme as university entrance examination in Nigeria education system?

(iii) What are the similarities and differences between lecturers' perspective of Gaokao and Waec/Utme in China and Nigeria?

The findings of this study provide empirical findings from lecturers' perspective of university entrance examination using Gaokao and Waec/Utme in China and Nigeria education system as there are no similar studies on this topic. The findings of this study expatiate on the similarities and differences between university entrance examination in both Gaokao and Waec/Utme within China and Nigeria education system.The findings of this study guide stakeholders (administrators of the universities, policy makers and researchers) not only in both China and Nigeria but also across the continents at large. Finally, findings of this study are of great benefit to universities and other institutions in both China and Nigeria on how to improve on university entrance examination. Geographically, the scope of this study was limited to China and Nigeria education system. Conceptually, the scope of this study concentrated on lecturers' perspective of university entrance examination in China and Nigeria education system. The study therefore examined lecturers' perspective of university entrance examination using Gaokao and Waec/Utme in China and Nigeria education system as a case study.

\subsection{LITERATURE REVIEW}

This section focuses on review of literatures on lecturers' perspective of university entrance examination in China and Nigeria education system. 
China Education System

Table 1: China Education System

\begin{tabular}{|c|c|c|c|c|c|c|c|}
\hline Education & School/Level & $\begin{array}{l}\text { Grade } \\
\text { From }\end{array}$ & $\begin{array}{l}\text { Grade } \\
\text { To }\end{array}$ & $\begin{array}{l}\text { Age } \\
\text { From }\end{array}$ & $\begin{array}{l}\text { Age } \\
\text { To }\end{array}$ & Years & Notes \\
\hline Primary & Primary School & 1 & 6 & 6 & 12 & 6 & $\begin{array}{l}\text { Primary education lasts } 6 \text { years and } \\
\text { it is intended for children aged 6-12. }\end{array}$ \\
\hline Secondary & $\begin{array}{l}\text { Junior (Lower) } \\
\text { Secondary } \\
\text { School }\end{array}$ & 7 & 9 & 12 & 15 & 3 & $\begin{array}{l}\text { Also known as chuzhong (初中) in } \\
\text { China. }\end{array}$ \\
\hline Secondary & $\begin{array}{l}\text { Senior (Upper) } \\
\text { Secondary/ } \\
\text { Vocational } \\
\text { Senior (Upper) } \\
\text { Secondary }\end{array}$ & 10 & 12 & 15 & 18 & 3 & $\begin{array}{l}\text { After the completion of junior } \\
\text { (lower) middle school, students can } \\
\text { choose to enter either general } \\
\text { (academic) senior secondary school } \\
\text { or vocational senior secondary } \\
\text { school. Vocational senior secondary } \\
\text { programs last } 3 \text { or } 4 \text { years. Senior } \\
\text { secondary school is known as } \\
\text { (gaozhong 高中) and vocational } \\
\text { senior secondary school is known as } \\
\text { (zhongzhuan 中专) in China. }\end{array}$ \\
\hline $\begin{array}{l}\text { Post- } \\
\text { secondary }\end{array}$ & $\begin{array}{l}\text { Undergraduate } \\
\text { Level - } \\
\text { Bachelor's } \\
\text { Degree }\end{array}$ & 13 & 16 & 18 & 22 & 4 & $\begin{array}{l}\text { Awarded upon completion of } \\
\text { programs requiring } 4 \text { to } 5 \text { years of } \\
\text { study, depending on the field of } \\
\text { study. Also know as (xueshi xuewei } \\
\text { 学士学位) in China. }\end{array}$ \\
\hline $\begin{array}{l}\text { Post- } \\
\text { secondary }\end{array}$ & $\begin{array}{l}\text { Graduate Level - } \\
\text { Master's Degree }\end{array}$ & 17 & 18 & 22 & 24 & 2 & $\begin{array}{l}\text { Awarded upon completion of } \\
\text { programs requiring } 2 \text { to } 3 \text { years of } \\
\text { education, depending on the major } \\
\text { field of study. Candidates may not be } \\
\text { older than } 35 \text { years of age. Also } \\
\text { known as (shuoshi xuewei 硕 } \pm \text { 学 } \\
\text { 位) in China. }\end{array}$ \\
\hline $\begin{array}{l}\text { Post- } \\
\text { secondary }\end{array}$ & $\begin{array}{l}\text { Graduate Level - } \\
\text { Doctoral Degree }\end{array}$ & 19 & 21 & 24 & 27 & 3 & $\begin{array}{l}\text { The completion of a master's degree } \\
\text { is required for admission to a } \\
\text { doctoral program. Doctoral programs } \\
\text { take } 3 \text { to } 5 \text { years to complete. It is } \\
\text { also possible to take a combined } \\
\text { master's/doctoral program in which } \\
\text { students are directly admitted to the } \\
\text { doctoral programs upon completing } \\
\text { the master's program. Students are } \\
\text { not awarded a master's degree in the } \\
\text { combined program and are awarded } \\
\text { with a doctoral degree at the end of } \\
\text { the program. This type of combined } \\
\text { program is known as (shuobo liandu } \\
\text { 硕博连读) in China. }\end{array}$ \\
\hline
\end{tabular}

Source: http://www.classbase.com

Education in China is a state-run system of public education run by the Ministry of Education. All citizens must attend school for at least nine years, known as the nine-year compulsory education, which the government funds. It includes six years of primary education, starting at age six or seven, and three years of junior secondary education (middle school) for ages 12 to 15 . Some provinces may have five years of primary school but four years for middle school. After middle school, there are three years of high school, which then completes the secondary education. The Ministry of Education reported a 99 percent attendance rate for primary school and an 80 percent rate for both primary and middle schools. In 1985, the government abolished tax-funded higher education, requiring university applicants to compete for scholarships based on academic ability. In the early 
1980s the government allowed the establishment of the first private school, increasing the number of undergraduates and people who hold doctoral degrees five fold from 1995 to 2005 (Xiufang, 2003). There are over 100 National Key Universities, including Peking University and Tsinghua University. Chinese spending has grown by $20 \%$ per year since 1999 , now reaching over $\$ 100 \mathrm{bn}$, and as many as 1.5 million science and engineering students graduated from Chinese universities in 2006. China published 184,080 papers as of 2008 (Xiulan, 2011). China has also become a top destination for international students (China Digital Times, 2013). As of 2013, China is the most popular country in Asia for international students, and ranks third overall among countries (China Digital Times, 2013).

China education is the largest education system in the world. On June 2016, there were 9.4 million students taking the National Higher Education Entrance Examination (Gao Kao) in China. Investment in education accounts for about 4\% of total GDP in China. In 1986, the Chinese government passed a compulsory education law, making nine years of education mandatory for all Chinese children. Today, the Ministry of Education estimates that 99.7 percent of the population area of the country has achieved universal nine-year basic education (http://www.chinaeducenter.com).

International students have enrolled in over 811 higher education institutions in China. China has a long history of providing education to international students studying in high schools and universities in China. Over the past few years, the number of international students who study abroad in China has significantly increased every year.

The higher education sector has growth as well. China is seeking to improve the quality of education through a major effort at curriculum reform. China has increased the proportion of its college-age population in higher education to over 20 percent now from 1.4 percent in 1978.

China has a consistent teacher development system. Teaching has historically been and remains today a highly respected profession in China. Teachers have strong preparation in their subject matter and prospective teachers spend a great deal of time observing the classrooms of experienced teachers, often in schools attached to their universities. Once teachers are employed in school, there is a system of induction and continuous professional development in which groups of teachers work together with master teachers on lesson plans and improvement. (http://www.chinaeducenter.com)

High school in China has different types of program for international students. There are programs for the following: students who plan to study Chinese in China; students who plan to apply to universities in China and students who want to study in English-taught high school programs.

International students should choose to study in local Chinese high school for studying Chinese language or preparing for admission to universities in China. Students enroll into Chinese high schools are able to spend more time with local Chinese students and participate in more local student's activities. There are programs designed for foreign students who have not learned Chinese language before. Students will take courses such as Chinese language, English, Mathematics and other Chinese cultural courses. (http://www.chinaeducenter.com)

No doubt, the trace of every entrance to higher education starts from the root of its elementary level. In China, primary school education is compulsory and it lasts 6 years. Children start schools at age six (seven in some areas). The language of instruction is Mandarin Chinese with the exception of the primary schools that mainly admit ethnic minority students. A typical school year is comprised of two semesters and runs from the month of September to July. Students attend classes five days a week and primary school education currently includes nine compulsory courses, which include Chinese, Mathematics, Social Studies, Nature, Physical Education, Ideology and Morality, Music, Fine Art, and Labor Studies. Foreign Language is normally offered as an elective course. In order to graduate, all students are required to pass graduation examinations in the subjects of Chinese and Mathematics. The examinations are normally designed and administered by schools with guidance from local educational authorities. Students move on to 3-year junior (lower) secondary schools (chuzhong 初中) after graduating from primary schools (www.classbase.com).

Junior (lower) secondary education, which serves as a middle education in China, lasts three years following the completion of primary school. In order for students to obtain a certificate of graduation, students are required to pass graduation examinations and meet minimum physical education standards. The graduation examinations are designed and administered by individual schools according to guidelines set by the provincial educational bureaus or by local educational authorities. Students are typically examined in the following subjects for graduation: Chinese, Mathematics, Chemistry, Physics, Foreign Language, and Politics. Completion of junior (lower) secondary education also marks the end of a 9-year (6+3) compulsory education program (www.classbase.com).

After the completion of junior (lower) secondary school, students can choose to enter either general (academic) senior secondary school or vocational senior secondary school. General (academic) senior secondary school lasts 3 years and vocational senior secondary school lasts 3 or 4 years. Senior secondary school is known as (gaozhong 高中) and vocational senior secondary school is known as (zhongzhuan 中专) in China. Students 
wishing to continue their study in the general (academic) track must pass the entrance examinations for general senior secondary schools, which is also known as (zhongkao 中考) in China. Designed and administered by provincial educational authorities, the entrance examination includes the same subjects as the junior secondary graduation examination. At the end of their final school year, graduates of senior secondary schools seeking admission to post-secondary education are required to take the National Higher Education Entrance Examination, also called National College Entrance Examination (NCEE), commonly known as (gaokao 高考) in China (www.classbase.com).

Vocational education programs are offered at both the secondary and post-secondary levels. Vocational senior secondary schools provide subject and occupation specific education and training. Vocational senior secondary education is highly employment oriented and graduates normally enter the workforce. However, it does offer some access to further education, particularly in the technical/vocational specialties. Since the year 2000, the Ministry of Education (MOE) has allowed graduates of vocational secondary schools to take the NCEE and be admitted into higher education programs.

Higher technical/vocational education is available at the zhuanke (专科) level, which require two or three years of full-time post-secondary study. It is possible for graduates of higher vocational education programs at the zhuanke level to obtain a "benke 本科" degree (Bachelor's degree) certificate through an upgrading program, but in a limited number of fields. Vocational higher education institutions are currently administered at the provincial level (www.classbase.com).

Higher education is provided by institutions of various types including general and technical universities, specialized institutions, professional universities, military institutions, medical schools and colleges, independent colleges, and adult higher education institutions of various types. Entry to university depends primarily on how well the students perform in the entrance examinations. Students with outstanding academic performance in their secondary schools can also possibly be granted an exemption from the entrance examination and be recommended directly to the university of their choice through a method called (baosong 保送). In addition, some private institutions are exempted from the NCEE (gaokao) and accept all students who can afford the tuition fees. Prestigious universities (key institutions) maintain higher admission standards, and therefore require higher NCEE (gaokao) scores than other institutions. Entry to higher education in China is highly competitive (www.classbase.com).

\subsection{Chinese Higher/University Entrance Examination and its relation to China's Education System: Gaokao.}

Before 1952, social background, academic qualification from school and family reputation played a vital role in the admission to higher education. After 1952, China set up the National University Entrance Examination which was abolished during the Great Cultural Revolution. By the year 1977, the Ministry of Education restore the National University Entrance Examination. Everyone less than 35 years of age had the opportunity to enter university after passing the required examination. The core subjects of university entrance examination were Mathematics, Chemistry, Chinese, Physics, Politics, English, History and Geography. Presently, China has 3 mandatory subjects (Mathematics, Chinese and English) with 1 extra subject for high school students to take in the National University Entrance Examination (Wang, 2010).

Liu haifeng and Liu liang (2017) divided the Gaokao reform into four stages: system recovery period, reform and adjustment period, enrolment expansion period and pilot deepening period, and they suggest that for the reform of Gaokao system, the contents and forms of examination should be continually changed according to the same principle of fairness. However, Liu enxian (2018) divided the Gaokao reform into three stages reform: in the first stage from 1978 to 1997, the core features were senior high school examinations and standardized tests. In the second stage from 1998 to 2009, the core features were the expansion of the enrolment scale, the subject setting and the reform of the propositional way. The third stage has the core features of classification examinations, comprehensive evaluation, and multiple ways of admission since 2010. Lin huiqing (2017) suggests that Opinions of the State Council on Deepening the Examination and Enrollment System Reform, promulgated in 2014, provides a blueprint and a new direction for a new round of College Entrance Examination reform. Moreover, Zhong binling and Wang xinfeng (2017) believe that the reform of Gaokao has the characteristics of gradual and continuous, showing the scientific, autonomous, selective and fair features of basic value orientation.

As to the relationship of Gaokao and China education system, Gaokao is the "baton" of primary and secondary education, and the selection tool for higher education. It is meant to achieve efficiency and fairness in the higher education entrance examination in China. (Ma jiansheng and Zou wei, 2018).

The education system in China has not ignored higher entrance examination, the country has been carrying out several reforms on higher entrance examination. China's reform on higher entrance examination aims at achieving scientific selection of talents and professionals, maintaining social justice and promoting healthy 
development of students. Among the objectives of the reform is to gradually form an examination and enrolment system that conforms to macro management by the government and implementation by professional organisations, respects independent enrolment policies by colleges and universities in accordance with the law of the land and provide students with manifold study choices, comprehensive evaluation, multilevel test and diversified admission (Jiao Gao, 2012). Presently, China's reform on higher entrance examination span through the following four reforms and promotions:

(i) Reforming the content and form of the higher entrance examination through the promotion of multilevel tests.

(ii) Reforming the examination evaluation system through promotion of comprehensive evaluation measures.

(iii) Reforming the admission model through fostering diversified forms of admission.

(iv) Reforming the higher entrance examination management system through the support of Sunshine Project. Generally, China will continue to abide by the higher entrance examination system in line with the reality and rules of the education system, in order to constantly improve the content and measures of the examination and the methods of enrolment and proceed with reforms in active and controlled manner (Jiao Gao, 2012).

Nigeria Education System

Figure 1: Education System in Nigeria.
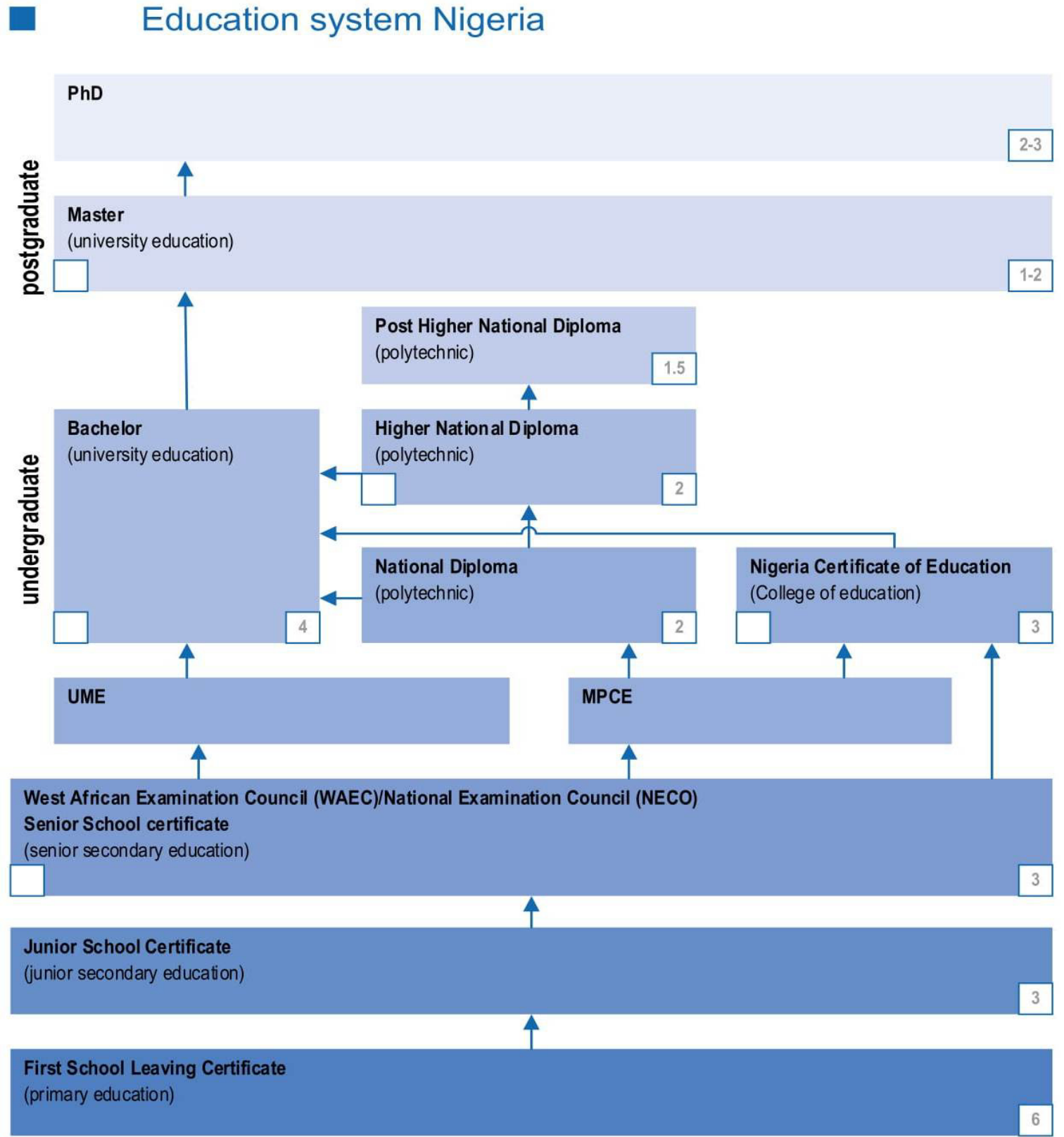

Source: Education system Nigeria | EP-Nuffic | 1st edition September 2009 | version 5, January 2015

Nigeria is a country of rich ethno cultural diversity with more than 350 distinct ethnic group and more than 
500 indigenous languages with an estimated population of over 170 million. The Nigeria education sector has the advantage of ample constitutional provisions and legislative support for the three tiers of government which are the Federal, State and Local government together with all other stakeholders to participate in the delivery of education at all levels. The constitution of the Federal Republic of Nigeria specifies the direction of national policy towards ensuring equal and adequate educational opportunities at all levels of education and the provision of compulsory, free and universal primary education together with free university education and free literacy programme provided they are all practicable.

It is the constitution that also provides the basic framework for the Federal, State and Local government in participating in the management and provision of education. Paragraphs 27 to 30 of part II in the second schedule of the constitution put education in the Concurrent List in which both the Federal and State governments participate. The provision and maintenance of primary, adult and vocational education is listed in paragraph 2(a) of the Fourth Schedule as one of the functions that Local governments can perform.

The Nigeria education system is structured in the following four stages:

Early Child Care and Development aged 0 to 4 years.

Basic Education aged 5 to 15 years. It encompasses Pre-Primary which is for 1 year, Primary Education which is for 6 years and Junior Secondary Education which is for 3 years.

Post-Basic Education which is 3 years for both Senior Secondary Schools and Technical Colleges.

Tertiary Education provided in Colleges of Education, Monotechnics, Polytechnics and the Universities (National Policy on Education, 2013).

\subsection{Nigeria Higher/University Entrance Examination and its relation to Education System: WAEC/UTME}

University entrance examination could be viewed as the process where students are examined and given admission to study in the university based on scores obtained in the examination. The reason for this university entrance examination might be because of the required skills that are needed for successful undergraduate course, applicants with these required skills are more than the available space in the universities. Thus, university entrance examinations are conducted in order to select candidates with the required skills to various departments in order to cope with the challenges of undergraduate courses. Anastasi (1988) contributed to the issue of university entrance examinations by distinguishing between selection and screening. Screening is used when candidates are examined in a consecutive manner during the early stage of examinations while selection is used when candidates are examined in a consecutive manner during final intensive stage of examinations. Screening could also be used in rapid rough selection processes.

University entrance examination or mode of admitting potential undergraduate students into Nigerian universities is Unified Tertiary Matriculation Examination (UTME) which is organised at the national level by the Joint Admissions and Matriculation Board (JAMB). A score of at least 200 from total score of 400 in the UTME is expected in most universities before taking part in the Post-Unified Tertiary Matriculation Examination (PUTME) which is organised by various universities. Both UTME and PUTME are the entrance examinations required for admission into Nigerian universities. Another reason for the PUTME is for the candidates' choice universities to select eligible ones who will not find it difficult to cope in the university.

Nigeria being colonised by Britain used General Certificate of Education (GCE) Advanced-Level that was organised by the University of Cambridge and University of London as university entrance examination till the establishment of West African Examination Council (WAEC) in 1951. WAEC conducts the West African Senior School Certificate Examination (WASSCE) known as Ordinary Level Certificate (O' Level) which is the university prerequisite entrance examination in West African Countries (Ghana, Nigeria, Sierra Leone, Gambia and Liberia). WASSCE is also prerequisite to sitting for UTME and PUTME in Nigeria.

After the establishment of WAEC in 1951, each university in Nigeria conducted individual entrance examinations for admission of candidates who had the O' Level certificate into the university till the year 1978. Among the problems during this period are varying standards of the different entrance examinations into the universities and multiple admissions. Harbor-Peter (1999) observed that there were vacant and unfiled spaces in some universities because of multiple admissions.

Afemikhe (2008) noted that there was lack of coordination in the admission system into universities. Omodara (2010) observed educational imbalance by disparity of educational opportunities between the regions in which the universities were sited and differing admission standards by different universities. Umo and Ezeudu (2007) also stated numerous irregularities in the matriculation examination which were conducted by various universities. There is therefore need for the stakeholders in the education sector to have a uniform central board that would control university entrance examination. This led to the establishment of the JAMB in 1976 and the first JAMB University Matriculation Examination (UME) was achievement-based test held in May 1978.

The establishment of JAMB was signed into law through Decree No.2 of 1978 by the then Federal Military Government of Nigeria, as an agency of the Federal Government and an examining body. Among the reasons for 
establishing JAMB are:

(i) reducing irregularities in West African Examinations Council's (WAEC) examination;

(ii) Avoiding multiple admission by the decentralized admission policy which denied others opportunity;

(iii) Ensuring comparability of standards across universities based on minimum standards requirements; and

(iv) Streamlining and co-ordinating admission practice in Nigeria.

JAMB periods between 1978 to 1992 had acceptable students' results for university admission as credit level in at least five relevant subjects from Senior School Certificate Examination (SSCE) conducted by the West African Examinations Council (WAEC) which should be obtained at not more than two sittings. In 1992, JAMB listed National Business Certificate and National Technical Certificate conducted by the National Business and Technical Examinations Board (NABTEB) as a prerequisite for admission into the universities, polytechnics and colleges of education.

Before the year 1999, the conduct of SSCE had been the exclusive preserve of WAEC, at April 1999 National Examinations Council (NECO) was created to take part in conducting Senior School Certificate Examination (SSCE) (JAMB, 2007). Success in NECO, NABTEB, SSCE and WAEC alone is not sufficient condition but only a necessary condition for admission; a pass in university entrance examination UME now UTME conducted by JAMB is also required (Agu, 2006). Since the year 2006, a pass in the UTME conducted by JAMB is not sufficient condition to enter university but only a necessary condition for admission; a pass in PUTME conducted by various universities is also required for admission into university.

As time went on, examination malpractices like impersonation and other became other of the day in the University Matriculation Examination (UME) organised by JAMB examination (JAMB, 2007). Ejinkonye (2004) confirmed high level of examination malpractices in the JAMB examination by presenting cases of alteration of candidates' grades in the JAMB office by JAMB officials. There was also massive cheating that was achieved by JAMB official in some JAMB centres. Candidates then preferred sitting for JAMB examination in some locations simply because of the ease of high scores. During this period examination malpractices became order of the day as parents, teachers, supervisors, examiners collaborate with students during and after JAMB examination, in order to obtain unmerited high scores (Ejinkonye, 2004).

A major reason for further screening Post-University Matriculation Examination (PUME) is lack of confidence in the validity of high scores paraded by many candidates in JAMB examination (Owie, 2007). Owie (2007) further found out that to a very large extent PUME has assisted universities in the screening and selection of admission process. Owie (2007) again presented cordial relationships between parents/guardians and university admission officers in the admission of candidates as one of the major critics of the PUME screening exercise. In spite of this and other critics, the Federal Executive Council (FEC) endorsed that universities in Nigeria should conduct the (PUME) screening exercise on 16th November, 2005 in Abuja (Ebiri, 2006).

University Matriculation Examination (UME) was later merged with Monotechnics, Polytechnics and Colleges of Education (MPCE) and became Unified Tertiary Matriculation Examination (UTME) in the year 2010 (Ursula, 2012). Also PUME was replaced with Post-Unified Tertiary Matriculation Examination (PUTME). The examination body believed that the merger will not only reduce pressure on the board but also bridge the discrimination between universities and polytechnics/colleges of education.

In the year $2014 \mathrm{JAMB}$ brought in computer-based testing (CBT). At the first year of CBT candidates were given option to choose either the CBT or paper and pencil based testing (PPBT). In the year 2015, JAMB made (CBT) compulsory for all candidates. In order to reduce if not eradicate examination malpractice in JAMB examination the body did not allow registration for the examination through any available cyber cafes, JAMB limited registration for the examination to accredited and limited centres not from any internet points in the year 2016.

Required scores in both UTME and PUTME constitute an important part in higher entrance examination in the Nigeria. Candidates would be admitted based on the aggregate/average performance of UTME and PUTME in relation to university departmental cut off point.

\subsection{Theoretical Framework}

This study focused on comparative analysis of lecturers' perspective on university entrance examination using Gaokao in China education system and Waec/Utme in Nigeria education system as a case study. From a theoretical perspective, the theory that impels this study is the classical test theory (CTT). The CTT was developed since early twentieth century. The theory was conceptualised on three main ideas: that error in measurement is real, that the real error is a random variable and lastly is how to index this error (Traub, 1997). Traub (1997) further stated that the assumption of CTT is that each candidate has a true score (T) which is obtained when there was no error in measurement. Candidate true score is then defined as expected number minus correct score. It is a pity that most examiners do not observe candidate's true score but only an observed score $(\mathrm{X})$. it is then assumed that observed score equal true score plus some error. Succinctly, $\mathrm{X}=\mathrm{T}+\mathrm{E}($ Observed score $=$ True score + Error $)$ 
CTT is therefore the observed score which is equal to the true score plus the error score. It focused on three variables: (X), (T) and (E). Omorogiuwa (2009) perceived variation in the observed score as the amount of random error change. Random error component approaches zero while the observed score approaches the true score, with negative effect of random error on both true and observed scores (Omorogiuwa, 2009). The true score $(\mathrm{X})$ shows the ability of the examinee. One of the problems of CTT is that it assumes all items to be equal. Among the advantages of CTT according to (Hambleton and Jones, 1993) are easy to apply in many testing situations (relatively weak theoretical assumption), according to (Fan, 1998) CTT considers a pool of examinees with examination of their success rate.

When the true score explains all of the variance of observed score then the test is perfect, such scenario can be used for university entrance examination. If the true score explains none of the variance of the observed score then the test is totally useless, in that scenario it cannot be used for university entrance examination.

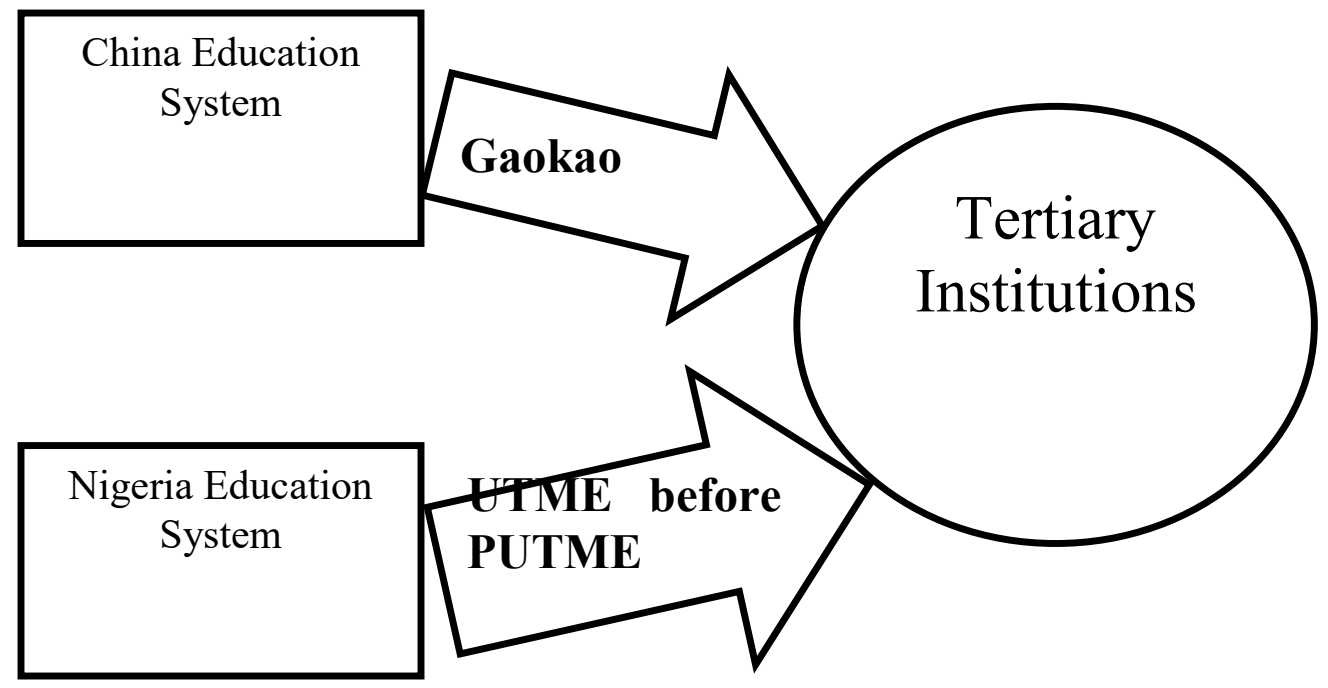

Source: Author 2018

\subsection{METHODOLOGY}

This section concentrates on adopted research method of the study. It also reveals research design, population of the study, sample and sampling strategy, research instrument and analytical strategy that will be used in the study.

\subsection{Research Design}

The research design that was used for this study is descriptive survey research design of the ex-post facto type. Descriptive survey research design was considered appropriate for this study because it provides the strategy for describing and obtaining existing conditions in the study without any manipulation from the researcher. The targeted population of this study consist of lecturers in University of Ibadan in Nigeria and Beijing Normal University in China. Purposive sampling technique was used to select University of Ibadan in Nigeria and Beijing Normal University in China while snowball sampling approach was used to select one hundred and nine lecturers in Beijing Normal University, China and one hundred and nine in University of Ibadan, Nigeria. The choice of snowball sampling is based on the nature of the study. Respondents are likely to know others who share the characteristics that make them eligible for inclusion in the study.

\subsection{Instrumentation}

The study made use of a combination of quantitative (questionnaires) and qualitative (interview) as the major source of data collection for this study. The quantitative data were collected through the use of questionnaires while the qualitative data were collected through the use of interview questions. The questionnaire for data collection was titled: A Comparative Analysis Of Higher Education Entrance Examination: A Case Study Of Chinese Gaokao And Nigeria Waec/Utme. The questionnaire was divided into two sections. The first section concentrates on the demographic data of the respondents. The second section focuses on the research questions of the study. Items in the questionnaire were rated on 5-point Likert scale type rated Strongly Agree (SA), Agree (A), Neutral (N), Disagree (D), Strongly Disagree (SD).

The qualitative data (interview questions) gather needed data for the study. Unstructured in-depth interviews and observation were instruments used for gathering qualitative data for the study. These methods were judged adequate because they helped provide in depth information, knowledge and special insight into the topic examined. The qualitative data were collected through In-depth Interview (IDI) and observation. Chinese 
data were collected online.

\subsection{Analytical Strategy}

Descriptive statistics of frequency counts were used to present perspectives of lecturers' on university entrance examination in China and Nigeria Education System.

\subsection{RESULTS}

This section centres on analysis of data and presentation of result. It also presented and discussed the findings of this study. Analysis of result was done in line with the research objectives and questions that were generated earlier in the study.

Table 1: Lecturers' Perspective of Gaokao

\begin{tabular}{|r|l|c|c|c|c|c|}
\hline $\mathrm{S} / \mathrm{N}$ & \multicolumn{1}{|c|}{ Statements } & $\mathrm{SA}$ & $\mathrm{A}$ & $\mathrm{N}$ & $\mathrm{D}$ & $\mathrm{SD}$ \\
\hline 1$)$ & $\begin{array}{l}\text { General knowledge, hand work, skills and ability of } \\
\text { students are tested in Gaokao examination }\end{array}$ & $\begin{array}{c}2 \\
(21.3)\end{array}$ & $\begin{array}{c}9 \\
(33.3)\end{array}$ & $\begin{array}{c}4 \\
(14.8)\end{array}$ & $\begin{array}{c}9 \\
(33.3)\end{array}$ & $\begin{array}{c}3 \\
(11.1)\end{array}$ \\
\hline 2$)$ & $\begin{array}{l}\text { Gaokao examination should not have absolute right to } \\
\text { university entrance examination }\end{array}$ & $\begin{array}{c}5 \\
(18.5)\end{array}$ & $\begin{array}{c}8 \\
(29.6)\end{array}$ & $\begin{array}{c}8 \\
(29.6)\end{array}$ & $\begin{array}{c}3 \\
(11.1)\end{array}$ & $(11.1)$ \\
\hline 3$)$ & $\begin{array}{l}\text { Individual university should play more roles than } \\
\text { Gaokao examination in university entrance } \\
\text { examination }\end{array}$ & $\begin{array}{c}7 \\
(25.9)\end{array}$ & $\begin{array}{c}8 \\
(29.6)\end{array}$ & $(18.5)$ & $\begin{array}{c}5 \\
(18.5)\end{array}$ & $(21.3)$ \\
\hline 4$)$ & $\begin{array}{l}\text { There should be another screening exercise for students } \\
\text { after passing Gaokao }\end{array}$ & $\begin{array}{c}4 \\
(14.8)\end{array}$ & $\begin{array}{c}15 \\
(55.6)\end{array}$ & $\begin{array}{c}(14.8) \\
(14.8)\end{array}$ & $\begin{array}{c}4 \\
(-.-)\end{array}$ \\
\hline 5$)$ & $\begin{array}{l}\text { High score in Gaokao does not determine the } \\
\text { performance during undergraduate }\end{array}$ & $\begin{array}{c}12 \\
(18.5)\end{array}$ & $\begin{array}{c}8 \\
(44.4)\end{array}$ & $(29.6)$ & $(3.7)$ & $(3.7)$ \\
\hline
\end{tabular}

Table 1 reveals lecturers' perspective of Gaokao as university entrance examination in China education system. The table shows that 11 (54.6) of the respondents agreed that general knowledge, hand work, skills and ability of students were tested in Gaokao examination, 13 (48.1) of the respondents agreed that Gaokao examination should not have absolute right to university entrance examination, 15 (55.5) of the respondents agreed that individual university should play more roles than Gaokao examination in university entrance examination, 19 (70.4) of the respondents agreed that there should be another screening exercise for students after passing Gaokao, 17 (62.9) of the respondents agreed that high score in Gaokao did not determine the performance during undergraduate. Based on the result from table 1, lecturers' perspective of Gaokao as university entrance examination in China education system is that there should be another screening exercise for students after passing Gaokao. This will take care of high number of students who are seeking admission into the university

Table 2: Lecturers' Perspective of Waec/Utme

\begin{tabular}{|r|l|c|c|c|c|c|}
\hline S/N & \multicolumn{1}{|c|}{ Statements } & SA & A & N & D & SD \\
\hline 1$)$ & $\begin{array}{l}\text { The standard of UTME is too high for entrance } \\
\text { examination into universities in Nigeria }\end{array}$ & $\begin{array}{c}6 \\
(30.0)\end{array}$ & $\begin{array}{c}- \\
(-.-)\end{array}$ & $\begin{array}{c}- \\
(-.-)\end{array}$ & $(70.0)$ & $(-.-)$ \\
\hline 2$)$ & $\begin{array}{l}\text { The presence of Post-UTME screening exercise for } \\
\text { students after passing UTME is the best. }\end{array}$ & $\begin{array}{c}14 \\
(70.0)\end{array}$ & $\begin{array}{c}6 \\
(30.0)\end{array}$ & - & - & - \\
$(-.-)$ & $(-.-)$ & $(-.-)$ \\
\hline 3$)$ & $\begin{array}{l}\text { High score in Post-UTME does not determine the } \\
\text { performance during undergraduate }\end{array}$ & - & 8 & - & 6 & 6 \\
$(-.-)$ & $(40.0)$ & $(-.-)$ & $(30.0)$ & $(30.0)$ \\
\hline 4$)$ & The grading score of Post-UTME is ambiguous & - & 6 & - & 14 & - \\
$(-.-)$ & $(30.0)$ & $(-.-)$ & $(70.0)$ & $(-)$. \\
\hline 5) & $\begin{array}{l}\text { Half of the overall score in Post-UTME should be } \\
\text { acceptable for admission into university }\end{array}$ & - & 14 & - & 6 & - \\
$(-.-)$ & $(70.0)$ & $(-.-)$ & $(30.0)$ & $(-.-)$ \\
\hline
\end{tabular}

Table 2 reveals lecturers' perspective of Waec/Utme as university entrance examination in Nigeria education system. The table shows that $6(30.0)$ of the respondents agreed that the standard of UTME was too high for entrance examination into universities in Nigeria, 20 (100.0) of the respondents agreed that the presence of Post-UTME screening exercise for students after passing UTME was the best, 8 (40.0) of the respondents agreed that high score in Post-UTME did not determine the performance during undergraduate, 6 (30.0) of the respondents agreed that the grading score of Post-UTME was ambiguous, 14 (70.0) of the respondents agreed that half of the overall score in Post-UTME should be acceptable for admission into university. Based on the result from table 2, lecturers' perspective of Waec/Utme as university entrance examination in Nigeria education system is that the presence of Post-UTME screening exercise for students after passing UTME was the best. The reason for this could be high examination malpractice in the UTME. 


\subsection{Comparison of lectures' perspective of Gaokao and Waec/Utme}

Lecturers' perspective of Waec/Utme as university entrance examination in Nigeria education system was that the presence of Post-UTME screening exercise for students after passing UTME was the best. This is in agreement with the lecturers' perspective of Gaokao as university entrance examination in China education system that there should be another screening exercise for students after passing Gaokao.

All the lecturers disagreed with the statement that the numbers of subjects in UTME examination in Nigeria education system are too much for students, while 8 (29.6) disagreed that subjects in Gaokao examination in China education system are too much for students.

14 (70.0) of the lecturers in Nigeria education system agreed that half of the overall score in Post-UTME should be acceptable for admission into university, while 14 (51.8) of the lecturers in China education system agreed that half of the overall score in Gaokao should be acceptable for admission into university.

\subsection{Comparative Analysis of Higher Education Entrance Examinations in Both Countries}

Below are few responses from respondents:

Question: What is your view about Gaokao examination as universities entrance examination?

\{LECTURER I.. MALE\}

"I think it is unreasonable to decide which university to enter the university only by relying on a college entrance examination. The examinee is influenced by many factors such as psychology, test paper difficulty, environment and so on. The grade of examinee in the examination room is not necessarily the true level of the examinee. The college entrance examination should be a comprehensive quality test."

\{LECTURER J FEMALE $\}$

Gaokao is one of the most important examinations of my life. As so many people said, it can decide our destiny. Only you are admitted into a famous and excellent university that can you be closer to a bright future. And it is a chance for some students in poor to change their life. Although there are so many shortages about gaokao, it is an unforgettable experience for one taking participation in gaokao. After it, you would learn how to concentrate on one thing and you would know the importance of hardworking and perseverance.

\{LECTURER H.. MALE.. \}

The college entrance examination is the entrance examination of the University. The college entrance examination results determine what school you will read. I think the college entrance examination is the only way for those rural children to succeed. In secondary school, you have to work hard to get a good result in the college entrance examination.

Most Nigerian respondents believe that UTME is not sufficient as universities entrance examination, but the addition of PUTME which is conducted independently by various universities. They believed that there should be a different test after the UTME examination.

Lecturers' perspective of Gaokao and Waec/Utme as university entrance examination in China and Nigeria respectively is that both examinations were tough and not easy to pass. While UTME requires PUTME before admission into Nigerian universities, Gaokao does not require additional exam before admission into Chinese universities.

Lecturers' perspective of Gaokao and Waec/Utme as university entrance examination in China and Nigeria respectively is that both examinations made students nervous and anxious which lead to failure in both examinations but failure in Gaokao can go to the extreme of psychological disease.

Both examinations had benchmarks for entering universities. These benchmarks seemed high in the students' perspective but not high in the lecturers' perspective. The benchmark in Gaokao allows students to enter universities in China while the benchmark in Waec/Utme only qualified students to take another examination in the chosen universities in Nigeria.

\subsection{Summary}

This study compared lecturers' perspective of university entrance examination using Gaokao and Waec/Utme in China and Nigeria education system as a case study. This study reviewed literatures that are relevant to university entrance examination in China and Nigeria education system. The study also concentrated on adopted research method of the study. A sample of 27 (twenty-seven) lecturers in China 20 (twenty) lecturers in Nigeria were used for the study. Three objectives with three research questions were generated for this study. Descriptive statistics of frequency counts were used.

The findings revealed that lecturers' perspective of Gaokao as university entrance examination in China education system is that there should be another screening exercise for students after passing Gaokao.

The findings also showed lecturers' perspective of Waec/Utme as university entrance examination in Nigeria education system is that the presence of Post-UTME screening exercise for students after passing UTME 
was the best.

Lastly the findings indicated that lecturers' perspective of Gaokao and Waec/Utme as university entrance examination in China and Nigeria respectively is that both examinations were tough and not easy to pass. While UTME requires PUTME before admission into Nigerian universities, Gaokao does not require additional exam before admission into Chinese universities.

\subsection{Conclusion}

Lecturers in China universities regarded Gaokao as tough for university entrance examination but wished for another screening exercise for students after passing Gaokao. Lecturers in Nigeria universities were contented with the presence of Post-UTME screening exercise by individual universities for students after passing UTME examination before gaining admission to universities in the country. Lecturers in China and Nigeria perceived Gaokao and Waec/Utme respectively as university entrance examination to be tough and not easy to pass. UTME required PUTME before admission into Nigerian universities while Gaokao did not require additional exam before admission into Chinese universities.

\subsection{Recommendations}

Based on the findings and conclusion drawn from this study, the following recommendations were made: Chinese government should embark on programmes that will reorientate Chinese students on all examinations especially university entrance examination Gaokao. Students should see exam as a text of knowledge and not a do or die affair. This will make them to be less nervous and reduce high rate of psychological disease. Chinese government should embark on reforming university entrance examination Gaokao. This reform is long overdue because of the long existence of Gaokao examination. When examination has been in existence for decades, there is tendency to be examination malpractice. Nigerian government should allow score obtained in the UTME to be used for admission for more than one year. This will reduce the high rate of students enrolling for the examination every year. Lecturers will also believe that UTME examination is not mere extortion from the populace.

\section{Reference}

Afemikhe, O. A. (2008). Selection into Nigerian universities students: assessment of post university matriculation examination. A paper presented at the 33rd Annual Conference of the International Association for Education Assessment in Africa (IAEA) held in Cambridge, UK. Retrieved August, 2, 2014. From http://www.iaea2008.cambridgeassessment.org./uk/ca/digtalAssets/180452_Afemikhe.pdf

Agu, N.N. (2006). A new trend of examination malpractice in Anambra State: The case of miracle centres. In A.A. Ekoja \& C.U. Mgboto (Eds.), Examinations in Nigeria: Appraisal Issues and Problems. Awka: Erudition Publishers.

Anastasi, A. (1988). Psychological Testing. New York: Macmillian Publishing co. Inc.

Bai, C., Chi, W., and Qian, X. (2014). Do college entrance examination scores predict undergraduate GPAs? A tale of two universities. China Economic Review, 30, 632-674. http://dx.doi.org/10.1016/j.chieco.2013.08.005

China Digital Times. 2013. "Education," Annotated aggregation of current Chinese media coverage. (4 February 2013).

Department of Development Planning, Ministry of Education, Yearbook of China Education Statistics (2010) (Beijing: People's Education Press, 2011),

Ebiri, K. (2006). Post-JAMB basis for admission says Obasanjo. Guardian, April 13, P. 49

Ejinkonye, U. (2004). Scrap JAMB, NECO, and save Nigeria education! Retrieved September 12, 2014 from www.information Nigeria. Org/2014

ESN, 2009. Education system Nigeria | EP-Nuffic | 1st edition September 2009 | version 5, January 2015.

Fan, X. (1998). Item Response Theory and Classical Test Theory: An Empirical Comparison of their Item/Person Statistics. Educational and Psychological Measurement, Sage Publication, Inc. 58 (3), 357-381.

Hambleton, R.K. \& Jones, R.W. (1993). Comparison of Classical Test Theory and Item Response Theory and their Application to Test Development. Educational Measurement: Issues and Practice, 12 (3), 535-556.

Harbor-Peter, V. F. (1999). Noteworthy points n measurement and evaluation. Enugu: Snaap Press Ltd.

http://www.chinaeducenter.com/en/cedu.php . accessed on 14-02-2017

http://www.chinaeducenter.com/en/cedu.php. accessed on 14-02-2017

http://www.chinaeducenter.com/en/schools.php. accessed on 14-02-2017

http://www.classbase.com/Countries/china/Education-System. accessed on 14-02-2017.

Jiao Gao, [Higher Education], No. 4 (2012). Opinions of the Ministry of Education on Improving the Higher Education in an All-Round Manner" Available online: http://www.gov.cn/zwgk/201204/20/content_2118168.htm. 
Joint Admission and Matriculation Board (2007). A study of the predictive validity of the universities matriculation (UME) 1998-2000. Lagos: Research, Monitoring and Evaluation Department, JAMB.

Kurian G. T. (1998). World Education Encyclopedia. New York.

Lin huiqing (2017) Drawing wisdom and strength from 40 years' reform of the college entrance examination, China Examinations, August, No.304, 1-3

Liu enxian (2018) The introspection and prospect of the policy changes of the college entrance examination during 40 years of reform and opening-up, China Higher Education Research No.5, 33-39

Liu haifeng and Liu liang (2017) Forty years of development since the recovery of Gaokao and its changes. Journal of Higher Education, Vol 38, No.10, 1-9

Ma jiansheng and Zou wei,(2018) The experience and lessons of China's college entrance examination reform in the past 40 years: a historical and comparative analysis, Journal of Southwest University (Social Science Edition) Vol.44, No.5 57-66

National Policy on Education, (2013). 6th Edition

Omodara, M.F. (2010). Assessment of the predictive validity of UME scores on academic performance of science university undergraduates. In Nwadiani, M. \& Jaja, J. (eds.). Multidisciplinary Journal of Research Development. 14, (1) 108-111.

Omorogiuwa, K.O. (2009). An Empirical Comparison of the Classical Test Theory and Item Response Theory in the selection of Physics achievement test items (Unpublished Doctoral Dissertation). University of Benin, Nigeria.

Owie, I. (2007). The impact of post-matriculation examination screening on reported cases of examination malpractice in a Nigerian university. A preliminary analysis: Proceedings of 1 st examination ethics conference of the University of Benin, Benin City.

Robin, M. H. (2008). University Admission World Wide. Education working paper series, number 15. International Bank for Reconstruction and Development/The World Bank July, 2008. Washington, D.C. USA.

Schroch, J. R. (2014). The Gaokao: The test where time stands still. University World News; the Global Window on Higher $\quad$ Education, China. $\quad$ Retrieved from http://www.universityworldnews.com/article.php?story=20140612091916875

Traub, R. (1997). Classical Test Theory in Historical Perspective. Educational Measurement: Issues and Practice, $16(4), 8-14$

Umo, U. \& Ezeudu, S.A. (2007). Relationship between university matriculation examination scores and the screening scores at the University of Nigeria, Nsukka. Paper presented at the 33rd Annual Conference of the International Association for Educational Assessment, Baku, Azerbajain. Retrieved November 10,2014 from http://iaea2007.tqdk.gov.az/cp/RELATIONSHIP\%20BETWEEN\%20UNIVERSITY\%20MATRICULATI ON\%20EXAMINATION\%SCORES.pdf.

Ursula, N.A. (2012). Relationship between gender and performance in Joint Admission University Matriculation Examination (UME) and the Post-UME. Journal of the Nigerian Academy of Education JONAED, 8 (2) $143-151$

Wang, P. (2010). China's new national education plan aims to build a country with rich human resources. Ministry of Education of the People's Republic of China. Retrieved from http://www.moe.edu.cn/publicfiles/business/htmlfiles/moe/ moe_2862/201010/109031.html.

www.ucas.com/how-it-all-works/advisers-and-referees/guides-and-resources

Xiufang Wang. 2003. Education in China since 1976. Jefferson, N.C.: McFarland \& Co., 2003. ISBN 0-78641394-8, ISBN 978-0-7864-1394-2.

Xiulan Zhang, 2011. China's Education Development and Policy, 1978-2008. Leiden; Boston: Brill, Social Scientific Studies in Reform Era China, 2011. xix, 480 p.p. ISBN 978-90-04-18815-0.

Zhong binling and Wang xinfeng (2017) The evolution and rational choice of value orientation of China's college entrance examination reform- text analysis of the policies in the past 40 years. Educational Research, No.10 General No 453, 12-20. 